Dr hab. prof. UŁ Katarzyna Kamila Walęcka-Matyja, https://orcid.org/0000-0001-8222-729X

Instytut Psychologii

Wydziat Nauk o Wychowaniu

Uniwersytet Łódzki

\title{
Wybaczanie i wdzięczność jako predykatory jakości relacji interpersonalnej dorosłych rodzeństw
}

\author{
Forgiveness and gratitude as predictors of the quality \\ of the interpersonal relationship of adults siblings
}

https://doi.org/10.34766/ fetr.v45i1.695

\begin{abstract}
Abstrakt: Cel pracy stanowiło określenie związków między wymiarami wybaczanie i wdzięczność a jakością relacji interpersonalnej rodzeństw w okresie wczesnej dorosłości, sprawdzenie czy stanowią one predyktory relacji interpersonalnej rodzeństw oraz, czy i $\mathrm{w}$ jaki sposób wymiary relacji interpersonalnej rodzeństw łączą się z motywami wybaczania.

Uczestnikami badań było 200 osób, znajdujących się w okresie wczesnej dorosłości $(M=24 ; S D=3,27)$, posiadających dorosłe rodzeństwo. Badania przeprowadzono w Polsce.

Zastosowano następujące narzędzia badawcze: Kwestionariusz Relacji Dorosłego Rodzeństwa (Walęcka-Matyja, 2014), Skalę Wybaczania (Charzyńska, Heszen, 2013), Kwestionariusz Powodów Przebaczania (Noworol, 2016), Kwestionariusz Gratitude Questionnaire (Kossakowska, Kwiatek, 2014) oraz ankietę.

Rezultaty badań wskazały na występowanie dodatniego związku między wdzięcznością a wymiarem relacji z rodzeństwem określanym jako Ciepło. Zmienna wybaczanie nie łączyła się w sposób istotny statystycznie z wymiarami relacji interpersonalnej dorosłych rodzeństw. Odnotowano występowanie istotnych, przebiegających $\mathrm{w}$ oczekiwanym kierunku związków między wymiarem relacji interpersonalnej rodzeństw Ciepło i powodami wybaczania. Predyktorem czynnika Ciepło w relacji dorosłych rodzeństw okazała się zmienna wdzięczność. Zmienna wybaczanie nie objaśniała żadnego z wymiarów z relacji interpersonalnej rodzeństw.
\end{abstract}

Słowa kluczowe: wdzięczność, wybaczanie, relacja interpersonalna, rodzeństwo, dorosłość

Abstract: The purpose of this study was to determine the relationships between forgiveness and gratitude and the quality of siblings' interpersonal relationship in early adulthood; and to test whether they are predictors of siblings' interpersonal relationship; and whether and how dimensions of siblings' interpersonal relationship are related to forgiveness motives. Study participants were 200 individuals in early adulthood $(M=24 ; S D=3.27)$ with adult siblings. The study was conducted in Poland. The following research tools were used: Adult Sibling Relationship Questionnaire (WalęckaMatyja, 2014), Forgiveness Scale (Charzyńska, Heszen, 2013), Reasons for Forgiveness Questionnaire (Noworol, 2016), Gratitude Questionnaire (Kossakowska, Kwiatek, 2014) and a questionnaire. The results of the study indicated that there was a positive relationship between gratitude and the sibling relationship dimension defined as Warmth. The forgiveness variable was not statistically significantly associated with adult sibling interpersonal relationship dimensions. Significant, in the expected direction, relationships were found between the sibling interpersonal relationship dimension Warmth and reasons for forgiveness. A predictor of the Warmth factor in adult sibling relationships turned out to be the gratitude variable. The forgiveness variable did not explain any of the dimensions from the siblings' interpersonal relationship.

Keywords: gratitude, forgiveness, interpersonal relationship, siblings, adulthood 


\section{Wprowadzenie}

W systemie rodzinnym wyjątkowy typ relacji interpersonalnej łączy osoby tworzące rodzeństwa (por. Szymańska, 2020; Walęcka-Matyja, 2018). Do najważniejszych cech tej relacji zalicza się pierwotny charakter oraz długotrwałość. Rodzeństwa wywodzą się z tego samego gniazda (Kasten, 1997), istnieją dzięki wspólnemu rodzicielstwu, co powoduje przymus przebywania z braćmi i siostrami, dostosowania się do nich, nawet jeśli niesie to ze sobą wiele trudnych emocji. Warto bowiem zauważyć, że relację z rodzeństwem, poza pozytywnymi aspektami opisują także konflikt, rywalizacja, a czasem nawet faworyzacja rodzicielska. Dlatego też $\mathrm{w}$ literaturze przedmiotu wskazuje się na ambiwalencję uczuć przejawianych przez rodzeństwa (Furman, Buhrmester, 1985). Unikatowość relacji łączącej rodzeństwo wiąże się także $\mathrm{z}$ niemożliwością odtworzenia jej $\mathrm{w}$ innych związkach interpersonalnych. Rodzeństwa bowiem posiadają wyjątkowe i wspólne doświadczenia rodzinne, dzielą historię rodzinną, wartości, tradycje kultywowane w rodzinie. $\mathrm{W}$ okresie dorosłości wspólnota doświadczeń jest wzmacniana przez utrzymywanie stosunków $\mathrm{z}$ rodzicami oraz rodziną rozszerzoną (Cicirelli, 1995).

W związku z tym, iż jest to najdłużej trwająca z relacji rodzinnych, może wystąpić wiele czynników, wpływających na kształtowanie się jakości tej relacji. Zalicza się tu zarówno liczne zmienne podmiotowe (np. płeć, wiek, osobowość, typ temperamentu, poziom umysłowy, poziom samooceny, stan zdrowia), jak i cały zewnętrzny kontekst środowiskowy, w którym człowiek żyje (np. wzorce kulturowe, wymagania społeczne, struktura i klimat rodziny pochodzenia, liczba rodzeństwa, jakość relacji małżeńskiej, style wychowania w rodzinie pochodzenia) (por. Szymańska, 2019; Walęcka-Matyja, 2018).

Stwierdzono, że jakość i zadowolenie z kontaktów interpersonalnych ma nieocenione znaczenie dla stanu zdrowia człowieka, zarówno w aspekcie fizycznym, jak i psychicznym. Wpływa także na poziom samooceny, a $\mathrm{w}$ rezultacie na satysfakcję $\mathrm{z}$ płynącą z funkcjonowania psychospołecznego (Czapiński, 2012; Dywer, 2005). Podane zależności odnoszą się także do relacji rodzeństw, co potwierdzają liczne doniesienia z tego zakresu (Rostowska, 2010; Szymańska, 2019; Walęcka-Matyja, 2018). Stąd zainteresowania naukowe skoncentrowano na czynnikach, które mogą odgrywać ważną rolę w kształtowaniu jakości relacji interpersonalnej rodzeństw - na umiejętności wybaczania i bycia wdzięcznym. Uważa się, że są one nabywane $\mathrm{w}$ toku socjalizacji, a także mogą być umacnianie podczas uczestnictwa w specjalistycznych treningach społecznych. Zaznacza się, że choć umiejętność wybaczania i bycia wdzięcznym uważane są przez psychologów za zmienne w istotny sposób wpływające na jakość relacji interpersonalnych, stan zdrowia oraz satysfakcję z życia (Kaleta, Mróz; 2018; Lyubomirsky, Sheldon, Schkade, 2005), to dotychczas nie rozpatrywano ich $\mathrm{w}$ aspekcie determinowania relacji interpersonalnej dorosłych rodzeństw. 


\section{Podstawy teoretyczne badań}

\subsection{Wybaczanie}

W psychologii znaczenie przebaczania dostrzegł już M. Rokeach (1973), włączając wartość instrumentalną "przebaczający” do badań, które prowadził nad preferencją wartości. Jednak prawdziwy rozkwit zainteresowania nad tym zagadnieniem przypadł na lata 80 XX wieku, gdy zwrócono uwagę na możliwość zastosowania przebaczenia w terapii osób skrzywdzonych, głównie ofiar przemocy domowej (Zarzycka, 2016).

Krzywda wyrządzona drugiemu człowiekowi powoduje $u$ niego stres, automatycznie uruchamiający procesy radzenia sobie $\mathrm{z}$ nim. Różnice indywidualne, osobowe, umiejętności i wcześniejsze doświadczenia z podobnymi sytuacjami w dużej mierze decydują o rodzaju odpowiedzi skrzywdzonego na zranienie. Osoba może szukać zemsty, pojednania, ucieczki lub może wybaczyć. Uważa się, że najodpowiedniejszym z rozwiązań jest rozpoczęcie procesu wybaczania, który w rezultacie prowadzi do obniżenia napięcia psychologicznego (Charzyńska, Heszen, 2013).

Badacze szeroko analizowali, w jaki sposób przebiega przebaczanie i które czynniki je warunkują. W efekcie opracowano wiele modeli teoretycznych, obrazujących to złożone zagadnienie. Ze względu na to, że dokładne omówienie każdego z nich wykracza poza tematykę podjętą $\mathrm{w}$ artykule zdecydowano się jedynie na przedstawienie założeń wybranych modeli o charakterze intra- $\mathrm{i}$ interpersonalnym $\mathrm{w}$ celu lepszego zrozumienia przebiegu procesu przebaczenia.

W modelu przebaczenia o charakterze procesualnym, intrapersonalnym autorstwa J. Mellibrudy (1995) i E. Woydyłło (1998) przebaczenie zostało ujęte jako sekwencja doświadczeń własnych stanów: bólu, lęku, gniewu, smutku, bezsilności, prowadzących $\mathrm{w}$ efekcie do uporządkowania na nowo wartości. Uważa się, że w procesie przebaczenia najistotniejsze jest zrozumienie doznanej krzywdy i powolne dochodzenie do decyzji o przebaczeniu, którego skutkiem psychologicznym jest ukształtowanie nowego ,ja". Autorzy wyróżnili następujące etapy tak rozumianego procesu przebaczenia: nazwanie krzywdy; rozpoznanie zmian spowodowanych przez krzywdę; określenie stopnia zniszczeń w osobowości; rozmowę o krzywdzie z krzywdzicielem lub kimś obiektywnym; uznanie krzywdy za własną; uznanie odpowiedzialności sprawcy; wyrównanie rachunków (np. uznanie sprawy za zamkniętą lub ukaranie krzywdziciela); odzyskanie poczucia wolności i mocy (Wojdyłło, 1998).

W modelach przebaczania o charakterze interpersonalnym rozpatrywany jest również aspekt behawioralny krzywdziciela, np. wyrażenie skruchy i chęci zadośćuczynienia oraz aktywność osoby skrzywdzonej np. odnowienie straconego zaufania w oparciu o wiarę (Martin, 1953), ponowne odkrycie wspólnoty (Augsburger, 1995). 
Uważa się, że pojawiająca się trudność przebaczenia drugiej osobie zależy od wielu czynników np. bliskości relacji, satysfakcji z relacji przed zranieniem, częstotliwości ponoszonych krzywd, siły poniesionego bólu, sytuacji, w jakiej doszło do popełnionego czynu. Podkreśla się, że odnosząc się do wybaczenia drugiemu człowiekowi, nie chodzi o wyzbycie się całkowicie trudnych emocji do danej osoby czy o zapomnienie, że określona sytuacja miała miejsce. Według badaczy poczucie gniewu nie jest złe, a nawet jest konieczne do rozpoczęcia procesu wybaczania (Stoop, 2002). Sądzi się, że niektóre z zachowań doprowadzających do zranienia mogą być na tyle silne, że nie da się ich odbudować, np. zachowania przemocowe $\mathrm{w}$ rodzinie. Krzywdziciel staje się osobą, z którą pozostali członkowie rodziny tworzą relacje oparte na strachu i przekonaniu, że zachowanie oparte na stosowaniu przemocy powtórzy się po raz kolejny. Zaufanie zostaje nieodwracalnie zniszczone (Hargrave, Sells, 1997).

Uważa się, że w systemie rodzinnym, ze względu na główne cechy odnoszące się do długotrwałości, wyjątkowości relacji łączących jego członków oraz specyfiki komunikacji rodzinnej często może dochodzić do zranień, których zrekompensowanie jest ocenianie jako możliwe. Sytuacja oraz doświadczenie krzywdy są tu specyficzne, bowiem rodzina jest tworzona przez osoby najbliższe i najważniejsze dla człowieka. Po zranieniu zwykle nadal utrzymywany jest kontakt $\mathrm{z}$ osobą, która dopuściła się zranienia, w mniejszym lub większym stopniu. Natomiast raczej nie jest możliwym, by całkowicie go zerwać. Podkreśla się także znaczenie poczucia lojalności względem członków rodziny, jak również poczucie zobowiązania względem siebie, $\mathrm{z}$ uwzględnieniem systemu międzypokoleniowego (Boszormeny-Nagy, Krasner, 1986).

W podsystemie rodzeństwa, w związku z tym, iż jest to najdłużej trwająca z relacji rodzinnych i często charakteryzująca się wysoką intensywnością uczuciową, możne wystąpić wiele powodów oraz sytuacji, w których dochodzi do zranienia. Najczęstsze tego przyczyny to agresja i przemoc występujące między rodzeństwem. Powołując się na rezultaty badań amerykańskich można stwierdzić, że agresji rodzeństwa doświadczyła ponad połowa badanych dzieci, a 15\% z nich zmaga się z nią na co dzień (Caffaro i ConnCaffaro, 2005; por. Poraj, Poraj-Weder, 2018).

W ujęciu Terr'ego D. Hargrave'a (1994) przebaczenie w rodzinie odnosi do dwóch kategorii, które określa jako uwalnianie oraz przebaczanie. Pierwsza z nich, uwalnianie dotyczy wysiłku, podejmowanego przez zranioną osobę, w celu zrozumienia i poradzenia sobie $\mathrm{z}$ doświadczanym bólem. Jest to możliwe poprzez dokonanie wglądu oraz zrozumienie. Natomiast przebaczanie, w odróżnieniu do uwalniania, wymaga podjęcia określonego zachowania, które odnosiłoby się do przyjęcia odpowiedzialności za wyrządzoną krzywdę przez jej sprawcę. Przebaczanie zachodzi poprzez stwarzanie możliwości oraz otwarty akt wybaczenia. Ważne jest zaangażowanie ze strony osoby skrzywdzonej, jak i krzywdziciela w celu podjęcia dialogu między nimi i próby 
odbudowania relacji. Ze strony krzywdziciela istotnym elementem $\mathrm{w}$ procesie pojednania jest przyznanie się do popełnionego czynu oraz gotowość do przyjęcia odpowiedzialności.

Odnosząc się do rodzeństwa silny wpływ, poza czynnikami osobowymi, na kształtowanie się zdolności do wybaczania mają rodzice. Często zdarza się, że zbyt mała uwaga poświęcana dziecku determinuje przeniesienie zawiści i trudnych emocji względem brata czy siostry. Jeżeli zaś rodzice okazują uwagę oraz uczucia obojgu z dzieci w takim samym stopniu, nie nasilają $\mathrm{w}$ ten sposób między nimi konfliktu czy rywalizacji. Relacje rodzeństw mają szansę stać się bardziej pozytywnymi. Ważnym jest, by już w dzieciństwie kształtować życzliwe i wspierające relacje między dziećmi. Z dużym prawdopodobieństwem ich jakość przeniosą w okres dorosłości. Istotnym jest to, żeby nie zmuszać do wybaczenia. Rodzeństwa trzeba uczyć tej umiejętności oraz dawać czas na zrozumienie danej sytuacji i oswojenie się $\mathrm{z}$ nią. Młody człowiek powinien poczuć chęć i potrzebę wybaczenia drugiej osobie.

Znaczenie prawidłowo funkcjonującej rodziny w kształtowaniu umiejętności wybaczania uzasadniają m.in. rezultaty badań Eufrozyny Gruszeckiej (2015). Analiza porównawcza trzech grup adolescentów, wychowywanych w domach dziecka, w rodzinach dysfunkcyjnych i rodzinach funkcyjnych pozwala stwierdzić, że wyższa zdolność do przebaczania ujawniła się $\mathrm{u}$ osób wychowanych $\mathrm{w}$ rodzinach prawidłowo funkcjonujących niż w dwóch pozostałych grupach (Gruszecka, 2015). Jak wskazuje autorka, uzyskane rezultaty wynikają $\mathrm{z}$ występowania $\mathrm{w}$ rodzinie szacunku, empatii, silnych więzi rodzinnych, co stanowi podstawę do odrzucenia obwiniania innej osoby. $Z$ kolei w innych badaniach zauważono, że wzajemne przebaczanie sobie przez członków rodziny wiąże się z pozytywną oceną własnej rodziny (Maio i in., 2008). Stwierdzono także, że z przebaczaniem $\mathrm{w}$ rodzinie jest związane zadowolenie z życia rodzinnego oraz satysfakcja z jakości komunikacji (Kaleta, Mróz, 2013).

W systemie rodzinnym codziennie dochodzi do różnorodnych interakcji, zarówno do tych, które mają charakter satysfakcjonujących, jak i tych, które wymagają przebaczenia np. konfliktowych. Można zauważyć, że w literaturze przedmiotu problematyka przebaczenia była dotychczas poruszana $\mathrm{w}$ odniesieniu do ogólnej tendencji rodziny do przebaczania (Pollard i in., 1998), w relacjach rodzic-dziecko (Maio i in., 2008) czy rozpatrywana w kontekście relacji zachodzących podsystemie małżeńskim (Paleari, Regalia, Fincham, 2005). Niedostatek badań nad przebaczaniem w relacji dorosłych rodzeństw skłonił do zainteresowania się tą problematyką. 


\subsection{Wdzięczność}

Za jednego z pierwszych badaczy, którzy zajmowali się wdzięcznością uznaje się filozofa i socjologa A. Smith'a. Według autora wdzięczność nie tylko przyczynia się do utrzymania równowagi i stabilności w społeczeństwie, ale stanowi także swoiste odwzorowanie dobra w stosunku do osoby, która świadczy jednostce dobro. Smith ujmował wdzięczność jako fundament życzliwości przejawianej w relacjach międzyludzkich (za: Kwiatek, 2012).

Wdzięczność można rozpatrywać w dwóch kategoriach, personalnej i transpersonalnej. Pierwsza $z$ nich ujawniana jest wobec określonych osób i wydarzeń z nimi związanych. Natomiast drugi rodzaj wdzięczności wykracza poza świat ludzkich relacji i jest ukierunkowany $\mathrm{w}$ stronę wyższego bytu, Boga, natury, ogólnie - życia. Przyjmuje się, że wdzięczność stanowi konstrukt o wielowymiarowym charakterze. Obejmuje bowiem swym zasięgiem nie tylko sferę emocjonalną, ale również obszary relacji społecznych, postaw moralnych, cech osobowych, zdolności adaptacji w środowisku (Emmons, McCullough, Tsang, 2002).

W psychologii opracowano wiele koncepcji dotyczących wdzięczności, a każda z nich opisuje i wyjaśnia to pojęcie w nieco inny sposób (por. Szcześniak, 2007). W niniejszej pracy za zasadne uznano przedstawienie głównych założeń koncepcji wdzięczności A. Maslowa (1941). Autor przyjmuje, że wdzięczność egzystencjalna jest jedną z pochodnych tzw. doznań szczytowych (ang. peak experiences). Tego typu sytuacje wywołują uczucia związane z uwielbieniem czy poczuciem spełnienia. Wtedy człowiek identyfikuje się z otaczającym go światem, zachowując jednocześnie odrębność. Badacz zwrócił uwagę na bardzo istotny element, który pojawia się w większości koncepcji, a mianowicie na jakość i bliskość relacji interpersonalnych, występujących między dobroczyńcą a odbiorcą dobra. Jeśli kontakty między jednostkami są pozytywne, pełne szacunku, zaufania to i dany czyn będzie uznany jako bezinteresowny, co wiąże się w następstwie z wdzięcznością drugiej strony. Natomiast kiedy relacje $\mathrm{z}$ drugą osobą nie należą do bliskich zachowanie takie, może być interpretowane jako podstęp lub próba manipulacji (za: Sieradzka-Baziur, 2017).

Uważa się, że wdzięczność bardzo wyraźnie wiąże się z relacjami interpersonalnymi. Dzięki okazywaniu wdzięczności, co można robić w sposób werbalny, jak i niewerbalny przez działania i przedmioty materialne, ludzie wzmacniają więzi interpersonalne. Odczuwanie i chęć podziękowania z biegiem czasu wpływa na umiejętności radzenia sobie ze stresem, człowiek staje się bardziej elastyczny pod względem działania i myślenia (Fredrickson, 2001).

Rozpatrując czynniki determinujące wdzięczność wskazuje się na ich trzy grupy. Za główny czynnik uważa się uwarunkowania genetyczne (50\%). Kolejną determinantą wdzięczności są czynniki zewnętrzne w stosunku do jednostki, które stanowią tylko 10\% 
całości. Do tego typu uwarunkowań zalicza się np. wpływ rodziny, kulturę, religię, warunki życia. Ostatnią z trzech wyróżnionych kategorii określających nasilenie wdzięczności jest własna aktywność jednostki (40\%) (por. Lyubomirsky, Sheldon, Schkade, 2005). Ze względu na podjętą w artykule problematykę warto zwrócić szczególną uwagę na znaczenie procesu wychowania w kontekście kształtowania wdzięczności. Przyjmuje się, że wyrażenie wdzięczności przez dziecko nie stanowi zachowania o spontanicznym charakterze, a pojawia się wraz z procesem rozwoju. Na podstawie przeprowadzonych badań ukazano, że starsze dzieci są częściej zdolne do okazania wdzięczności niż młodsze, co związane jest z rozwojem sfer poznawczej i moralnej (Grief i Gleason, 1980). Ponadto w badaniach potwierdzono rolę oddziaływań rodzicielskich oraz środowiska zewnętrznego $\mathrm{w}$ procesie socjalizacji odczuwania i wyrażania wdzięczności. Porównując dwie grupy rodziców, tj. rodziców zaangażowanych $\mathrm{w}$ proces wychowania, uwzględniających wzmacnianie pozytywnych przejawów wdzięczności i rodziców, którzy nie kształtowali wdzięczności $\mathrm{u}$ swych dzieci zauważono odmienne efekty wychowawcze. Dzieci rodziców z grupy opisanej jako pierwsza w 86\% wykazywały zdolność do bycia wdzięcznym, natomiast tylko 7\% dzieci rodziców z drugiej grupy okazywało wdzięczność (za: Kwiatek, 2012).

Liczne wyniki badań potwierdzają, że wdzięczność wpływa na wszystkie sfery życia człowieka, do których zaliczane są: zdrowie fizyczne, aspekt psychiczny oraz życie społeczne (Kossakowska, Kwiatek, 2014). Odwołując się do wpływu wdzięczności na stan zdrowia fizycznego zauważono, że osoby wyrażające wdzięczność mimo uciążliwości płynących z doświadczania choroby przewlekłej, miały lepsze rokowania niż osoby prezentujące postawę obwiniającą. Ludzie doceniający życie takie, jakie jest dużo łatwiej znosili pobyt w szpitalu oraz obowiązującą dietę. Wyniki badań pacjentów skupiających się na emocjach pozytywnych, w tym wdzięczności wykazywały dużo lepszą komunikację między sercem a mózgiem (Gruszecka, 2011). W nawiązaniu do aspektu psychicznego można zauważyć silną korelację między wyrażaniem wdzięczności a zdrowiem psychicznym. Osoby okazujące wdzięczność stają się bardziej otwarte na doświadczenia, czerpią więcej radości z życia. Charakteryzują się też wzrostem poziomu nadziei oraz optymizmu (Kossakowska, Kwiatek, 2014). Z kolei koncentrując zainteresowania naukowe na sferze życia społecznego, zauważono, że ludzie okazujący wdzięczność są obdarzani większym zaufaniem, gdyż dużo rzadziej przyjmują postawę oceniającą innych. Dzięki ujawnianiu wdzięczności i wykonywaniu wielu czynności prospołecznych mogą zyskać grono przyjaciół i znajomych (Kossakowska, Kwiatek, 2014). Świadome przeżywanie wdzięczności zapobiega izolowaniu się od innych. Bycie z innymi i dla innych dodaje człowiekowi energii do dalszego działania (Kwiatek, Wilczewska, 2014). Umiejętność dziękowania skutkuje nawiązywaniem trwalszych oraz bliższych relacji interpersonalnych. Osobom uważanym za wdzięczne łatwiej układa się współpraca z innymi ludźmi, gdyż szanują zdanie każdego z członków grupy (Gruszecka, 2011). Choć w dotychczas 
zaprezentowanych w literaturze przedmiotu badaniach nad wdzięcznością poruszono wiele interesujących kwestii, określenie czy wdzięczność stanowi determinantę jakości relacji interpersonalnej dorosłych rodzeństw nadal wymaga eksploracji naukowej na polskim gruncie.

\section{Badania własne}

\subsection{Cel badań}

Sformułowano trzy cele badań. Pierwszy $\mathrm{z}$ nich stanowiło sprawdzenie, $\mathrm{w}$ jaki sposób jakość relacji interpersonalnej dorosłych rodzeństw wiąże się ze zdolnością do wybaczania i wdzięczności. Zrealizowanie drugiego celu służyło określeniu czy występują związki między motywami wybaczania a wymiarami relacji interpersonalnej rodzeństw. Ostatnim celem badania było wskazanie czy i w jaki sposób zdolność do wybaczania i wdzięczności wpływa na wymiary relacji dorosłych rodzeństw.

W oparciu o literature przedmiotu sformułowano pytania i hipotezy badawcze.

1. Czy i w jaki sposób jakość relacji interpersonalnej z dorosłym rodzeństwem wiąże się z wdzięcznością $\mathrm{w}$ grupach badanych kobiet i mężczyzn?

H1.1. W grupie badanych kobiet wdzięczność dodatnio koreluje z relacją rodzeństwa opartą na czynniku Ciepło.

H1.2. W grupie badanych mężczyzn wdzięczność dodatnio koreluje z relacją rodzeństwa opartą na czynniku Ciepło.

H1.3. W grupie badanych kobiet wdzięczność ujemnie koreluje z relacją rodzeństw opartą na czynniku Konflikt.

H1.4. W grupie badanych mężczyzn wdzięczność ujemnie koreluje z relacją rodzeństw opartą na czynniku Konflikt.

H1.5. W grupie badanych kobiet wdzięczność ujemnie koreluje z relacją rodzeństw opartą na czynniku Rywalizacja.

H1.6. W grupie badanych kobiet wdzięczność ujemnie koreluje z relacją rodzeństw opartą na czynniku Rywalizacja.

2. Czy i w jaki sposób jakość relacji interpersonalnej z dorosłym rodzeństwem wiąże się ze zdolnością do wybaczania w grupach badanych kobiet i mężczyzn?

H2.1. W grupie badanych kobiet wybaczanie dodatnio koreluje z relacją rodzeństw opartą na czynniku Ciepło.

H2.2. W grupie badanych mężczyzn wybaczanie dodatnio koreluje $\mathrm{z}$ relacją rodzeństw opartą na czynniku Ciepło.

H2.3. W grupie badanych kobiet wybaczanie ujemnie koreluje $\mathrm{z}$ relacją rodzeństw opartą na czynniku Konflikt. 
H2.4. W grupie badanych mężczyzn wybaczanie ujemnie koreluje z relacją rodzeństw opartą na czynniku Konflikt.

H2.5. W grupie badanych kobiet wybaczanie ujemnie koreluje z relacją rodzeństw opartą na czynniku Rywalizacja.

H2.6. W grupie badanych mężczyzn wybaczanie ujemnie koreluje z relacją rodzeństw opartą na czynniku Rywalizacja.

3. Czy i w jaki sposób powody wybaczania wiążą się $\mathrm{z}$ wymiarami relacji interpersonalnej dorosłych rodzeństw?

4. Czy wdzięczność i wybaczanie wpływają na jakość relacji interpersonalnej dorosłych rodzeństw?

\subsection{Metoda i osoby badane}

Badaniami objęto 200 dorosłych osób (N1=100 mężczyzn oraz N2=100 kobiet) znajdujących się w okresie wczesnej dorosłości $(M=24 ; S D=3,27)$. Osoby te posiadały dorosłe rodzeństwo $\mathrm{w}$ przedziale wiekowym 18-48 lat $(\mathrm{M}=26,5 ; \mathrm{SD}=17,56)$. Więcej niż połowa badanych zamieszkiwała tereny miejskie (58\%). Pozostałe $42 \%$ mieszkało na wsi. Zdecydowana większość respondentów studiowała lub pracowała (96,5\% badanych, w tym 25,5\% łączyło oba zajęcia). Analizując uzyskane dane można zauważyć, że 57,5\% stanowiły osoby nie znajdujące się aktualnie w bliskim związku.

W przypadku badanej grupy, w odniesieniu do kwestii posiadanego rodzeństwa stwierdzono, że znaczącą część respondentów stanowiły osoby będące najmłodszymi z rodzeństwa $(44 \%)$ oraz najstarszymi $(39 \%)$. Urodzonych w rodzeństwie jako dzieci środkowe było zaledwie 17\% ankietowanych. Okazało się, że 27,5\% badanych osób aktualnie mieszka z rodzeństwem. Kontakt z rodzeństwem zadeklarowało 96,5\% badanych. Przez 3,5\% respondentów kontakt pośredni np. w formie rozmów telefonicznych bądź mailowych nie został potraktowany jako forma utrzymywania kontaktu. Określając relacje interpersonalne z rodzeństwem ponad połowa badanych, oceniła je jako życzliwe i ciepłe (63,5\%), a jedynie 6\% uznało je za chłodne. Opisując deklaracje uczestników badania w zakresie określenia częstości kłótni z rodzeństwem, stwierdzono, że 85,5\% osób ocenia, że rzadko kłóci się z rodzeństwem, a 25,5\% stwierdza, że się wcale nie kłóci. Jednym z ostatnich aspektów funkcjonowania dorosłych rodzeństw stanowiła ocena jakości wspomnień relacji z rodzeństwem oraz ich obszaru. Zdecydowana większość ankietowanych określiła te wspomnienia jako pozytywne (73,5\%). W większości dotyczyły spędzania ze sobą wolnego czasu $(78,5 \%)$ oraz udzielania pomocy w sytuacjach rodzinnych (10,5\%). Pozostałe $11 \%$ osób nie miało wspomnień lub były one neutralne bądź negatywne. 


\subsection{Procedura i materiały}

Badania o charakterze samoopisowym przeprowadzono w latach 2017-2018 $\mathrm{w}$ ramach prowadzonego przeze mnie seminarium magisterskiego. Zastosowano celowy dobór badanych do grupy. Kryteria włączenia były następujące: wiek (18-35 lat), płeć badanych, posiadanie biologicznego rodzeństwa, w wieku co najmniej 18 lat.

Badanie wykonano metodą CAWI (ang. Computer Assisted Web Interview). Uważa się, że badanie internetowe jest najczęściej używane w przypadku prowadzenia badań o charakterze ilościowym (Siuda, 2016). Zaletami stosowania tej metody jest szybkość pozyskania określonej liczby badanych osób, jak również fakt, że osoby badane mogą wypełnić zestaw testów w dogodnym dla siebie czasie. Nie ma też określonego czasu na wypełnienie testów. Co ważne, w przypadku ogólnodostępnych narzędzi psychologicznych nie ponosi się kosztów związanych z przeprowadzeniem badania. Istotną kwestią jest także bieżąca możliwość kontrolowania uzyskanych wyników. Spore ułatwienie stanowi samoistne tworzenie się bazy danych, w której zapisane są wszystkie odpowiedzi respondentów, co nie wymaga własnoręcznego kodowania (Babbie, 2004).

Warto zaznaczyć, że pomimo wskazanych wyżej pozytywnych aspektów badań prowadzonych za pomocą metody CAWI nie pozostaje ono pozbawione wad. Najistotniejsze z nich odnoszą się do nikłej możliwości kontroli czynników zewnętrznych, wpływających na wynik końcowy oraz niemożność weryfikacji, co do wprowadzanych przez respondenta danych np. (wiek, płeć). W związku z trudnością kontroli, wbrew pozorom obserwuje się dość niski procent zwrotów wypełnionych ankiet, co może być spowodowane potraktowaniem danego zestawu testów jako spamu. Istotnie słabą stroną badań internetowych jest też brak możliwości wyjaśnień niejasności pojawiających się w trakcie wypełniania testów, co może skutkować niezrozumieniem i zaznaczeniem fałszywej odpowiedzi (Siuda, 2016).

Badani, we wprowadzeniu do udziału w projekcie naukowym zostali poproszeni o wyrażenie zgody, poinformowani o celu badań, zapewnieni o anonimowości, o wykorzystaniu wyników wyłącznie w celach naukowych oraz, że w każdej chwili mogą odmówić udziału w badaniu bez ponoszenia konsekwencji.

Analizy statystyczne przeprowadzono przy użyciu programu IBM SPSS 24 na licencji Uniwersytetu Łódzkiego.

W badaniach zastosowano następujące narzędzia badawcze: Kwestionariusz Relacji Dorosłego Rodzeństwa (w adaptacji Walęckiej-Matyja, 2014), Skalę Wybaczania (w adaptacji Charzyńska, Heszen, 2013), Kwestionariusz Powodów Przebaczania (Noworol, 2016), Kwestionariusz Wdzięczności (w adaptacji Kossakowskiej i Kwiatka, 2014) oraz ankietę.

Kwestionariusz Relacji Dorosłego Rodzeństwa w adaptacji Walęckiej-Matyja (2014) jest polską wersją kwestionariusza Adult Sibling Relationship Questionnaire (ASRQ) (Stocker, Lanthier, Furman, 1997). Wykorzystano go w celu dokonania pomiaru psychologicznych 
aspektów relacji interpersonalnej dorosłych rodzeństw. Kwestionariusz ten pozwala określić percepcję zachowań i uczuć badanych wobec rodzeństwa, jak również postrzeganie u rodzeństwa zachowań oraz uczuć przejawianych wobec badanych. Relacja interpersonalna z rodzeństwem ujmowana jest trójczynnikowo i obejmuje następujące czynniki: Ciepło, Konflikt i Rywalizację. KRDR składa się z 81 itemów, które tworzą 14 skal: Uczucia, Wiedza, Bliskość, Wsparcie Emocjonalne, Podziw, Podobieństwo, Wsparcie Instrumentalne, Akceptacja, Przeciwieństwo, Dominacja, Kłótnia, Konkurencja, Rywalizacja Matczyna, Rywalizacja Ojcowska. Badana osoba ustosunkowuje się do twierdzeń zawartych w kwestionariuszu poprzez dokonanie ich oceny na skali Likerta od "prawie wcale" (1 punkt) do „bardzo dużo” (5 punktów). KRDR cechuje wysoka zgodność wewnętrzna o czym świadczą wartości współczynnika rzetelności a - Cronbacha, zawierające się w przedziale 0,87 - 0,97 (Walęcka-Matyja, 2014).

Skala Wybaczania (Toussaint Williams, Musik oraz Everson, 2001, w opracowaniu Charzyńskiej, Heszen, 2013) została zastosowana w celu oszacowania trzech odrębnych wymiarów, jakimi są: wybaczanie sobie, wybaczanie innym oraz poczucie wybaczenia od Boga. Skala składa się z 9 itemów, do których badany ustosunkuje się udzielając odpowiedzi na 5-stopniowej skali Likerta. Rzetelność i trafność narzędzia jest dobra, umożliwiająca prowadzenie badań naukowych (Charzyńska, Heszen, 2013).

Kwestionariusz Powodów Przebaczania powstał z myślą o terapii osób nieradzących sobie z krzywdą (Noworol, 2016). Składa się z 67 pozycji, z których wyodrębniono dziewięć głównych czynników. Należą tu: motywy religijne (odnosi się do powodów związanych z wiarą), powodów uczuciowych (dotyczy poczucia miłości i sympatii do drugiego człowieka), motywów związanych z przeprosinami (związane jest $\mathrm{z}$ tym, czy przeprosiny są warunkiem koniecznym do wybaczenia), motywów związanych $z$ wolnościq (dotyczy własnego oczyszczenia związanego z wybaczeniem drugiej osobie), powodów sprawiedliwości (wiąże się z oceną relacji z krzywdzicielem), powodów zwiazanych z naprawianiem krzywdy (odnosi się do stosunku osoby badanej względem trudności wybaczenia i tego, jak dużo czasu potrzebuje, aby wybaczyć), trudności pojednania (mówi o tym, czy dla badanego przebaczenie jest równoznaczne z pojednaniem) $i$ wspótczucia (nawiązuje do cierpienia bliźnich i doznawanie pośrednio przez to krzywdy). Każda ze skal posiada zadowalającą rzetelność, która przyjmuje wartość a - Cronbacha w przedziale od 0,52 do 0,85 oraz trafność umożliwiającą prowadzenie badań naukowych (Noworol, 2016).

Kwestionariusz Gratitude Questionnaire (McCullough, Emmons i Tsang, 2002) zastosowano w celu określenia zdolności do wdzięczności. Autorami polskiej adaptacji kwestionariusza są Marlena Kossakowska i Piotr Kwiatek (2014). Po badaniach pilotażowych, jak i analizie czynnikowej $\mathrm{w}$ polskiej adaptacji pozostawiono jednoczynnikową strukturę kwestionariusza. Rzetelność okazała się niższa niż w wersji oryginalnej natomiast osiągnęła ona stopień zadowalający, a mianowicie a- Cronbacha=0,71. 
Kwestionariusz składa się z sześciu pozycji odnoszących się do jednego czynnika, a badany ustosunkowuje się do twierdzeń na 7-stopniowej skali Likerta (Kossakowska, Kwiatek, 2014).

Zastosowanie ankiety miało na celu zebranie danych demograficzno-społecznych, takich jak: wiek, płeć badanych, ich miejsce zamieszkania, status związku, aktywność zawodowa, częstość kontaktu i ocena relacji z rodzeństwem, obszary wspomnień.

\section{Wyniki badań}

Na mocy Centralnych twierdzeń granicznych przyjęto, że rozkład analizowanych zmiennych jest zbliżony do normalnego. Twierdzenia te mówią o tym, że im bardziej zwiększa się liczebność badanej grupy, tym rozkład jest bardziej zbliżony do rozkładu normalnego (Szymczak, 2010). Do oszacowana związków między uwzględnionymi w badaniu zmiennymi zastosowano współczynnik korelacji r- Pearsona oraz analizę regresji $\mathrm{w}$ odmianie wprowadzania.

\subsection{Zależności między wymiarami relacji $\mathrm{z}$ rodzeństwem a wdzięcznością} i wybaczaniem

Przedstawione wyniki badań ukazują związki między wymiarami relacji interpersonalnej dorosłych rodzeństw a wybaczaniem i wdzięcznością (tab.1). Przeprowadzone analizy zmiennych uwzględniały podział badanych ze względu na płeć. Do pomiaru zależności między badanymi zmiennymi zastosowano współczynnik korelacji rPearsona.

Tabela 1. Zależności między wymiarami relacji dorosłych rodzeństw a wybaczaniem i wdzięcznością

\begin{tabular}{|l|c|c|c|c|}
\hline Jakość relacji & \multicolumn{2}{|c|}{ Kobiety $(\mathrm{n}=100)$} & \multicolumn{2}{c|}{ Mężczyźni $(\mathrm{n}=100)$} \\
\hline & Wdzięczność & Wybaczanie & Wdzięczność & Wybaczanie \\
\hline Ciepło &, $226^{\star *}$ &, 023 &, $394^{* *}$ &,- 074 \\
\hline Rywalizacja &,- 067 &,- 057 &,- 024 &, 029 \\
\hline Konflikt &,- 036 &,- 064 &, 039 &,- 068 \\
\hline
\end{tabular}

*korelacja istotna na poziomie $p<0,05$ ** korelacja istotna na poziomie $p<0,001$

Rozpatrując wyniki przedstawione $\mathrm{w}$ tabeli $\mathrm{nr} 1$ można stwierdzić, że zarówno w grupie kobiet, jak i mężczyzn występuje słaba oraz dodatnia korelacja między wdzięcznością a relacją opartą na życzliwych relacjach $\mathrm{z}$ dorosłym rodzeństwem. $\mathrm{W}$ przypadku pozostałych zmiennych nie ujawniły się istotne statystycznie korelacje. Tym 
samym pozytywnie zweryfikowano hipotezy H1.1 i H1.2. Natomiast hipotezy H1.3, H1.4, H1.5, H1.6, H2.1, H2.2, H2.3, H2.4, H2.5, H2.6 nie zostały potwierdzone.

\subsection{Zależności między powodami wybaczania a wymiarami relacji z rodzeństwem}

W następnym kroku analiz sprawdzano występowanie korelacji między powodami wybaczania a wymiarami relacji z dorosłym rodzeństwem $\mathrm{w}$ grupach kobiet (tabela $\mathrm{nr} 2$ ) i mężczyzn (tabela nr 3).

Tabela 2. Zależności między motywami wybaczania i wymiarami relacji interpersonalnej rodzeństw w grupie kobiet

\begin{tabular}{|c|c|c|c|}
\hline & \multicolumn{3}{|c|}{$\begin{array}{l}\text { Wymiary relacji interpersonalnej } \\
\text { z dorosłym rodzeństwem }\end{array}$} \\
\hline $\begin{array}{l}\text { Kategorie motywów } \\
\text { wybaczania }\end{array}$ & Ciepło & Konflikt & Rywalizacja \\
\hline Motywy religijne & 176 & 047 & 057 \\
\hline Motywy uczuciowe & 189 & , 050 &,- 177 \\
\hline $\begin{array}{l}\text { Motywy związane } \quad \text { z } \\
\text { przeprosinami }\end{array}$ & 062 & 140 &,- 079 \\
\hline Motywy związane z wolnością & 193 & 033 &,- 019 \\
\hline Powody sprawiedliwości & 066 & 010 & 038 \\
\hline $\begin{array}{l}\text { Motywy związane } \\
\text { naprawieniem krzywdy }\end{array}$ & $237^{* *}$ &,$- 284^{* *}$ &,- 052 \\
\hline $\begin{array}{l}\text { Motywy związane } \\
\text { trudnością pojednania }\end{array}$ & $-243^{*}$ & 034 & 110 \\
\hline Motywy współczucia & 166 &,- 095 & 054 \\
\hline
\end{tabular}

*korelacja istotna na poziomie $\mathrm{p}<0,05$ **korelacja istotna na poziomie $\mathrm{p}<0,001$

Rozpatrując wyniki przedstawione $\mathrm{w}$ tabeli 2 zauważono, że otrzymane, istotne statystycznie korelacje odnoszą się do powodów wybaczania związanych z naprawianiem krzywdy a Ciepłem i Konfliktem. Stwierdzono, że bardziej życzliwe relacje wiążą się dodatnio z motywem wybaczania odnoszącym się do zrekompensowania krzywdy. Z kolei druga zaobserwowana zależność wskazuje, że bardziej konfliktowe relacje z rodzeństwem związane są z mniejszym prawdopodobieństwem wystąpienia motywu wybaczania opartego o chęć zrekompensowania krzywdy. Zaznacza się, że oba związki mają słabą siłę. Ostatni istotny statystycznie związek miał charakter ujemny i słaby, a odnosił się do zależności między wymiarem Ciepło a motywem wybaczenia określonym jako trudności w pojednaniu. Stwierdzono, że im bardziej życzliwe relacje z rodzeństwem, tym mniejsze 
trudności z wybaczaniem i pojednaniem. W pozostałych przypadkach nie odnotowano istotnych statystycznie zależności między analizowanymi zmiennymi.

Tabela 3. Zależności między motywami wybaczania i wymiarami relacji interpersonalnej rodzeństw w grupie mężczyzn

\begin{tabular}{|c|c|c|c|}
\hline & \multicolumn{3}{|c|}{$\begin{array}{l}\text { Wymiary relacji interpersonalnej } \mathrm{z} \\
\text { dorosłym rodzeństwem }\end{array}$} \\
\hline $\begin{array}{l}\text { Kategorie motywów } \\
\text { wybaczania }\end{array}$ & Ciepło & Konflikt & Rywalizacja \\
\hline Motywy religijne & $227^{*}$ & ,031 &,- 081 \\
\hline Motywy uczuciowe & $225^{*}$ & ,098 & 156 \\
\hline $\begin{array}{l}\text { Motywy związane } \\
\text { z przeprosinami }\end{array}$ &,- 048 & ,090 & 152 \\
\hline $\begin{array}{l}\text { Motywy związane } \\
\text { z wolnością }\end{array}$ & 177 & ,013 &,- 072 \\
\hline Powody sprawiedliwości & 143 &,- 037 & ,088 \\
\hline $\begin{array}{l}\text { Motywy związane } \\
\text { z naprawieniem krzywdy }\end{array}$ & $296^{* *}$ &,- 160 & 172 \\
\hline $\begin{array}{l}\text { Motywy związane } \\
\text { z trudnością pojednania }\end{array}$ & ,002 & ,023 & ,052 \\
\hline Motywy współczucia & $246^{*}$ &,- 169 & ,089 \\
\hline
\end{tabular}

*korelacja istotna na poziomie $\mathrm{p}<0,05$ **korelacja istotna na poziomie $\mathrm{p}<0,001$

Rozpatrując rezultaty badań (tabela nr 3) odnoszące się do związków między wymiarami relacji interpersonalnej rodzeństw i powodów wybaczania w grupie mężczyzn zaobserwowano, że wystąpiło ich więcej niż w grupie kobiet. Istotne statystycznie korelacje ujawniono między wymiarem Ciepło a motywami związanymi z potrzebą naprawienia krzywdy, ze współczuciem, motywami religijnymi i uczuciowymi. Zaznacza się, że wymienione korelacje miały charakter dodatni i słaby. W pozostałych przypadkach nie odnotowano istotnych statystycznie zależności między analizowanymi zmiennymi.

\subsection{Wdzięczność i wybaczanie jako predyktory wymiarów relacji z rodzeństwem}

W ostatnim etapie analiz poszukiwano odpowiedzi na pytanie o wpływ wdzięczności i wybaczania na jakość relacji interpersonalnej dorosłych rodzeństw. W tym celu zastosowano wielokrotną analizę regresji liniowej, w odmianie metody wprowadzania. Metoda ta polega na wprowadzaniu do modelu kolejno zmiennych niezależnych 
niebędących jeszcze w równaniu (Szymczak, 2010). Decyzję o zastosowaniu tego podejścia podjęto, aby pokazać po wprowadzeniu, której zmiennej wzrasta istotność (znaczenie) szacowana dla całego modelu, co się z tym wiąże, która zmienna niezależna istotnie wyjaśnia zmienną zależną. Przyjęto, że zmiennymi niezależnymi są wdzięczność i wybaczanie, a zamiennymi zależnymi Ciepło, Konflikt i Rywalizacja. Uzyskane rezultaty przedstawiono w tabelach 4-6.

Tabela 4. Wyniki analizy regresji w grupach kobiet i mężczyzn - predyktory wymiaru Ciepło

\begin{tabular}{|l|l|l|l|l|l|}
\hline $\begin{array}{l}\text { Predyktory } \\
\text { Wdzięczność }\end{array}$ & $\mathrm{R}^{2}$ & $\beta$ & $\mathrm{F}$ & $\mathrm{t}$ & $\mathrm{p}$ \\
\hline kobiety &, 051 &, 360 & 5,259 & 2,293 &, 024 \\
\hline mężczyźni &, 155 &, 363 & 17,976 & 4,240 &, 000 \\
\hline Wybaczanie & $\mathrm{R}^{2}$ & $\beta$ & $\mathrm{F}$ & $\mathrm{t}$ & $\mathrm{p}$ \\
\hline kobiety &, 052 &, 069 & 2,676 &, 373 &, 074 \\
\hline mężczyźni &, 157 &, 066 & 9,030 &, 476 &, 043 \\
\hline
\end{tabular}

$\mathrm{R}^{2}$ - współczynnik determinacji; Beta - standaryzowany współczynnik regresji; F- wartość testu $\mathrm{F}, \mathrm{t}$ - wartość testu $\mathrm{t} ; \mathrm{p}$ - poziom istotności

Rozpatrując wpływ zmiennych niezależnych na zmienną zależną Ciepło stwierdzono, że zarówno w grupie kobiet, jak i mężczyzn większe nasilenie wdzięczności wpływało na większe nasilenie czynnika Ciepło w relacjach dorosłych rodzeństw. Zmienna wdzięczność odpowiednio wyjaśniała (w grupie kobiet) 41\% wariancji zmiennej zależnej Ciepło, natomiast w drugim przypadku (w grupie mężczyzn) 14,6\%. Wyniki w modelu ze zmienną wybaczanie okazały się nieistotne statystycznie.

Tabela nr 5. Wyniki analizy regresji w grupach kobiet i mężczyzn - predyktory wymiaru Konflikt

\begin{tabular}{|l|l|l|l|l|l|}
\hline $\begin{array}{l}\text { Predyktory } \\
\text { Wdzięczność }\end{array}$ & $\mathrm{R}^{2}$ & $\beta$ & $\mathrm{F}$ & $\mathrm{t}$ & $\mathrm{p}$ \\
\hline kobiety &, 001 &,- 044 &, 125 &,- 353 &, 725 \\
\hline mężczyźni &, 002 &, 030 &, 151 &, 389 &, 698 \\
\hline Wybaczanie & $\mathrm{R}^{2}$ & $\beta$ & $\mathrm{F}$ & $\mathrm{t}$ & $\mathrm{p}$ \\
\hline kobiety &, 006 &,- 095 &, 274 &,- 066 &, 761 \\
\hline mężczyźni &, 005 &,- 073 &, 243 &,- 580 &, 785 \\
\hline
\end{tabular}

R²- współczynnik determinacji; Beta - standaryzowany współczynnik regresji; F- wartość testu $\mathrm{F}, \mathrm{t}$ - wartość testu $\mathrm{t} ; \mathrm{p}$ - poziom istotności 
Omawiając wyniki uzyskane w grupach kobiet i mężczyzn (tabela nr 5) zauważono, że zmienne wdzięczność i wybaczanie nie objaśniały zmiennej Konflikt, a żaden z modeli nie okazał się istotny statystycznie.

Tabela 6. Wyniki analizy regresji w grupach kobiet i mężczyzn - predyktory wymiaru Rywalizacja

\begin{tabular}{|l|l|l|l|l|l|}
\hline $\begin{array}{l}\text { Predyktory } \\
\text { Wdzięczność }\end{array}$ & $\mathrm{R}^{2}$ & $\beta$ & $\mathrm{F}$ & $\mathrm{t}$ & $\mathrm{p}$ \\
\hline kobiety &, 005 &,- 061 &, 444 &,- 667 &, 507 \\
\hline mężczyźni &, 001 &,- 013 &, 055 &,- 234 &, 815 \\
\hline Wybaczanie & $\mathrm{R}^{2}$ & $\beta$ & $\mathrm{F}$ & $\mathrm{t}$ & $\mathrm{p}$ \\
\hline kobiety &, 008 &,- 065 &, 445 &,- 607 &, 668 \\
\hline mężczyźni &, 001 &, 020 &, 053 &, 228 &, 948 \\
\hline
\end{tabular}

$\mathrm{R}^{2}$ - współczynnik determinacji; Beta - standaryzowany współczynnik regresji; F- wartość testu $\mathrm{F}, \mathrm{t}$ - wartość testu $\mathrm{t} ; \mathrm{p}$ - poziom istotności

Podsumowując rezultaty uzyskane w grupach kobiet i mężczyzn (tab.6) zauważono, że zmienne wdzięczność i wybaczanie nie objaśniały zmiennej Rywalizacja, a żaden z modeli nie okazał się istotny statystycznie.

\section{Dyskusja wyników}

W przeprowadzonych badaniach psychologicznych celem było określenie związków między wymiarami wybaczanie i wdzięczność a jakością relacji interpersonalnej rodzeństw w okresie wczesnej dorosłości, sprawdzenie czy stanowią one predyktory relacji interpersonalnej rodzeństw oraz czy i w jaki sposób wymiary relacji interpersonalnej rodzeństw łączą się z motywami wybaczania.

Uzyskane rezultaty badań pozwalają stwierdzić, że zarówno w grupie kobiet, jak i mężczyzn ujawnił się słaby, dodatni związek między wdzięcznością a relacją opartą na życzliwych relacjach z dorosłym rodzeństwem (Ciepło). Rodzeństwa, które cechowały się prawidłową, wpierającą relacją częściej były skłonne okazywać sobie wdzięczność. Choć kierunek zależności jest zgodny z przewidywaniami, to zaskakuje jej mała siła. Możliwe, że zdolność do bycia wdzięcznym nie była mocno nasilona u badanych, młodych osób. W literaturze przedmiotu wskazuje się na wiele czynników ograniczających możliwość ujawniania wdzięczności, a do najważniejszych zaliczane są: uboga refleksyjność, ograniczenia $\mathrm{w}$ wyrażaniu wdzięczności związane ze stereotypowym postrzeganiem roli kobiety i mężczyzny, postrzeganie siebie jako ofiary, bezsilnej i niezdolnej do zarządzania 
rzeczywistością, w której żyje, poczucie należności, wyrażające się w niedostrzeganiu roli innych osób pomagających $\mathrm{w}$ osiągnięciu upragnionego celu, osobowość narcystyczna, zaabsorbowanie dobrami materialnymi oraz nieadekwatne oddziaływania ze strony środowiska wychowawczego (Kwiatek, 2012).

W prezentowanych wynikach badań nie ujawniono istotnego statystycznie związku między wybaczaniem a wymiarami relacji interpersonalnej dorosłych rodzeństw. Można sądzić, że wynika to z faktu, że na okres wczesnej dorosłości przypada czas zwiększania się dystansu w ich relacjach i stopniowego uwalniania spod wpływów rodzicielskich. Według J.L. Tanner (2005) powód powyższego stanowi zachodząca zmiana w zainteresowaniach młodych dorosłych. W mniejszym niż dotychczas stopniu są oni skoncentrowani na stosunkach rodzinnych, a bardziej zainteresowani nawiązywaniem nowych, pozarodzinnych relacji. Okres między 20 a 35 rokiem życia uznaje się za czas znaczącej transformacji relacji z rodzeństwem (Szymańska, 2020).

Wśród badaczy panuje przekonanie, że jakość relacji braci i sióstr w okresie wczesnej dorosłości jest determinowana wydarzeniami życiowymi. Zdecydowana większość ludzi w wieku od 20 do 35 roku życia przechodzi przez te same wydarzenia życiowe, tj.: opuszczenie rodzinnego domu, zakończenie edukacji, podjęcie roli zawodowej, założenie rodziny oraz posiadanie dzieci. Stopień zaangażowania się w realizację tych zadań sprawia, że w większości dorośli członkowie podsystemu rodzeństwa przejawiają relacje o słabej sile (Mouw, 2005), co prawdopodobnie nie stwarza powodów oraz przestrzeni do okazywania wybaczania. W celu potwierdzenia tego przypuszczenia można przywołać dane uzyskane $\mathrm{w}$ ankiecie, $\mathrm{z}$ których wynika, że uczestnicy badania $\mathrm{w}$ zdecydowanej większości deklarowali $(85,5 \%)$, że rzadko kłócą się z rodzeństwem, a 25,5\% uznało, że wcale się nie kłóci z rodzeństwem.

Odnosząc się do związków występujących między wymiarami relacji interpersonalnej rodzeństw i powodami wybaczania stwierdzono, że ujawniły się one w oczekiwanym kierunku w obydwu grupach. Zaznacza się, że w grupie mężczyzn wystąpiło ich więcej niż w grupie kobiet, co oznacza, że odgrywały one tu ważniejszą rolę. Im bardziej pozytywne relacje, w większym stopniu oparte na czynniku Ciepło, tym bardziej wybaczanie $\mathrm{w}$ grupie mężczyzn wiązało się z motywami kierowanymi chęcią naprawienia krzywdy, doświadczania współczucia, motywami religijnymi oraz uczuciowymi. Z kolei $\mathrm{w}$ grupie kobiet bardziej życzliwe relacje z rodzeństwem łączyły się dodatnio z motywem wybaczania opartym o chęć naprawienia krzywdy. Z kolei, im wyraźniej kobiety oceniały relacje z rodzeństwem jako cechujące się konfliktowością, tym $\mathrm{w}$ mniejszym stopniu ich wybaczanie opierało się na skłonności do naprawienia wyrządzonej krzywdy. Odnosząc się do pozytywnej oceny relacji w grupie kobiet, stwierdzono, że wybaczanie $\mathrm{w}$ tym przypadku $\mathrm{w}$ mniejszym stopniu bazowało na motywie trudności wynikających z pojednania. Zaznacza się, że wymienione wyżej korelacje miały charakter istotny statystycznie, ale słaby. 
W pozostałych przypadkach nie odnotowano znaczących statystycznie zależności między analizowanymi zmiennymi.

Poszukując odpowiedzi na pytanie o to, czy wdzięczność i wybaczanie są predyktorami wymiarów jakości interpersonalnej rodzeństw przeanalizowano wyniki, uzyskane osobno dla grup kobiet i mężczyzn. Okazało się, że jedynie zmienna wdzięczność stanowiła predyktor życzliwych, opartych na czynniku Ciepło relacji dorosłych rodzeństw. Większe nasilenie wdzięczności wpływało na większe nasilenie czynnika Ciepło w relacjach braci i sióstr. Przy czym w grupie kobiet wdzięczność wyjaśniała większy procent wariancji wyników (41\%) niż w grupie mężczyzn (14,6\%). Interpretując otrzymany rezultat można odnieść się do potwierdzonego przez psychologów zróżnicowania w ekspresji wdzięczności między kobietami a mężczyznami. Mężczyzn postrzega się bowiem jako bardziej powściągliwych i rzadziej skłonnych do jej komunikowania (Kashdan i in., 2009).

Dla pełnego omówienia uzyskanych w badaniu wyników należy zwrócić uwagę na ich ograniczenia. Jedno $\mathrm{z}$ nich dotyczy zastosowania narzędzi samoopisowych. Choć zaznacza się, że wszystkie $\mathrm{z}$ nich miały parametry psychometryczne adekwatne dla prowadzenia badań naukowych, to jednak z natury są one obarczone podatnością na wpływ czynników sytuacyjnych. Przy kolejnych badaniach nad wdzięcznością i wybaczaniem ujawnianych w relacji rodzeństw, a w szczególności nad wybaczaniem, warto zastosować także metody jakościowe. Podejście to może przyczynić się do poznania i analizowania na głębszym poziomie podjętych zagadnień. Dla uzyskania większej możliwości generalizowania wyników warto uwzględnić w badaniach także osoby znajdujące się w dwóch pozostałych okresach dorosłości, tj. średniej i późnej. Być może zastosować dobór celowy do próby, uwzględniający osoby, które doświadczyły w relacji z rodzeństwem krzywdy, zranienia i te, które nie miały takich doświadczeń. Co prawda, cel i charakter tych badań byłby inny niż przedstawiony w pracy, porównawczy, nie korelacyjny, ale z pewnością przyczyniający do poszerzenia wiedzy psychologicznej z tego obszaru.

Podjęcie badań, których rezultaty zaprezentowano $\mathrm{w}$ pracy było inspirowane ogólnym wzrostem zainteresowania psychologów pozytywnymi aspektami doświadczenia ludzkiego (por. Seligman, 2005). Uważa się, że poszukiwanie psychologicznych predyktorów relacji interpersonalnych $\mathrm{z}$ bliskimi osobami, $\mathrm{w}$ tym $\mathrm{z}$ rodzeństwem ma wyjątkowo istotne znaczenie dla człowieka. W Polsce, w społeczeństwie familocentrycznym wartość relacji z rodzeństwem jest nieoceniona. Jeśli jest ona harmonijna może nadawać życiu sens, umożliwiać zaangażowanie się, a także kojarzyć z przyjemnością. W myśl założeń psychologii pozytywnej sprzyja to rozkwitowi dobrostanu psychologicznego oraz wzrostowi poczucia spełnienia (Gulla, Tucholska, 2007). 


\section{Bibliografia:}

Augsburger, D.W. (1995). Sztuka przebaczania, Warszawa: Vocatio.

Babbie, E. (2004). Badania społeczne w praktyce, Warszawa: PWN.

Boszormenyi-Nagy, I., Krasner, B. (1986). Between give and take: A clinical guide to contextual therapy, New York: Brunner/Mazel.

Caffaro, J.V., Conn-Caffaro, A. (2005). Treating sibling abuse families, Aggression and Violent Behavior, 10, 604-623.

Charzyńska, E., Heszen, I. (2013). Zdolność do wybaczania i jej pomiar przy pomocy polskiej adaptacji Skali Wybaczania L.L. Toussainta, D.R. Williamsa, M.A. Musicka i S.A. Everson, Przeglad Psychologiczny, 4 (56), 423-446.

Cicirelli, V.G. (1995). Sibling relationships across the life span, New York: Plenum.

Czapiński, J. (2012). Psychologiczne teorie szczęścia, (w:) J. Czapiński (red.), Osobowość szczęśliwego człowieka, 359-379, Warszawa: PWN.

Dywer, D. (2005). Bliskie relacje interpersonalne, Gdańsk: GWP.

Emmons, R.A., McCullough, M.E., Tsang, J. (2002). The assessment of gratitude, (in:) S. Lopez, C.R. Snyder (eds.), Handbook of positive psychology assessment, 327-342, American Psychological Association.

Fredrickson, B. (2001). The role of positive emotions in positive psychology. The Broaden and Build theory of positive emotions, American Psychologist, 3 (56), 218-226.

Furman, W., Buhrmester, D. (1985). Children's perceptions of the qualities of sibling relationships, Child Development, 56, 448-461.

Greif, E.B., Gleason, J.B. (1980). Hi, thanks, and goodbye: More routine information, Language in Society, 9, 59-66.

Gruszecka, E. (2011). Wdzięczność a szczęśliwe życie, Psychologia Społeczna, 19 (64), 316-329.

Gruszecka, E. (2015). Środowisko wychowawcze a poczucie krzywdy, wrażliwość na pokrzywdzenie i wybaczanie we wczesnej adolescencji, Psychologia Rozwojowa, 4 (20), 45-57.

Gulla, B. Tucholska, K. (2007). Psychologia pozytywna: cele naukowo-badawcze i aplikacyjne oraz sposób ich realizacji, (w:) P. Francuz, W. Otrębski (red.). Studia z Psychologii w KUL, 14, 133-152. Lublin: Wydawnictwo KUL.

Hargrave, T.D. (1994). Families and forgiveness: a theoretical and therapeutic framework, The Family Journal, 2 (4), 339-348.

Hargrave, T.D., Sells, J.N. (1997). The development of a forgiveness scale, Journal of Marital and Family Therapy, 23, 41-63.

Kaleta, K., Mróz, J. (2013). Struktura relacji w rodzinie pochodzenia a poczucie wsparcia i osamotnienia, Społeczeństwo i Rodzina, 2 (35), 87-104.

Kaleta, K., Mróz, J. (2018). Forgiveness and life satisfaction across different age groups in adults, Personality and Individual Differences, 1 (120), 17-23. 
Kashdan, T.B., Mishra, A., Breen, W.E., Froh, J.J. (2009). Sex differences in gratitude: Examining appraisals, narratives, emotion expressivity, and changes in psychological needs, Journal of Personality, 77, 691-730.

Kasten, H. (1997). Rodzeństwo. Ideaty, rywale, powiernicy, Warszawa: Wydawnictwo Springer PWN.

Kossakowska, M., Kwiatek, P. (2014). Polska adaptacja kwestionariusza do badania wdzięczności GQ-6, Przegląd Psychologiczny, 4 (57), 503-514.

Kwiatek, P. (2012). Przeszkody i strategie rozwoju wdzięczności w świetle współczesnych badań psychologicznych, Seminare, 32, 151-163.

Kwiatek, P., Wilczewska, K. (2014). Klucz do szczęścia, Charaktery, grudzień, 32-35.

Lyubomirsky, S., Sheldon, K.M., Schkade, D. (2005). Pursuing happiness: The architecture of sustainable change, Review of General Psychology, 9, 111-131.

Maio, G.R., Thomas, G., Fincham F.D., Carnelley, K.B. (2008). Unraveling the Role of Forgiveness in Family Relationships, Journal of Personality and Social Psychology, 2 (94), 307-319.

Martin, A.J. (1953). A realistic theory of forgiveness, (in:) J. Wild (ed.), The return to reason, 313-332, Chicago: Henry Regnery.

Mellibruda, J. (1995). Pułapka niewybaczonej krzywdy, Warszawa: Instytut Psychologii Zdrowia i Trzeźwości, Polskie Towarzystwo Psychologiczne.

Mouw, T. (2005). Sequences of early adult transitions: A look at variability and consequences, (in:) R.A. Settersten, F.F. Jr Furstenberg, R.G. Rumbaut (eds.), On the frontier of adulthood: Theory, research and public policy, 256-291, Chicago: University of Chicago Press.

Noworol, A.M. (2016). Kwestionariusz Powodów Wybaczania, Czasopismo Psychologiczne, 1 (22), 141-159.

Paleari F.G., Regalia, C., Fincham F.D. (2005). Marital quality, forgiveness, empathy, and rumination: A longitudinal analysis, Personality and Social Psychology Bulletin, 31, 373374.

Pollard, M.W., Anderson, R.A., Anderson, W.T., Jennings, G. (1998). The development of family forgiveness scale, Journal of Family Therapy, 1 (20), 95-109.

Poraj, G., Poraj-Weder, M. (2018). Agresja pomiędzy rodzeństwie-ciemna strona socjalizacji w rodzinie, Psychologia Wychowawcza, 14, 155-172.

Rokeach, M. (1973). The nature of human values, New York: Free Press.

Rostowska, T. (2010). Psychospołeczne aspekty relacji interpersonalnych $\mathrm{w}$ podsystemie rodzeństwa bliźniąt monozygotycznych, (w:) T. Rostowska, B. PastwaWojciechowska (red.), Rozwój bliźniąt w ciagu życia. Aspekty biopsychologiczne, 101-122, Kraków: Impuls. 
Seligman, M. (2005). Prawdziwe szczęście. Psychologia pozytywna o urzeczywistnieniu nowych możliwości trwałego spetnienia, Poznań: Wydawnictwo Media Rodzina.

Sieradzka-Baziur, B. (2017). Pojęcie WDZIĘCZNOŚĆ - semantyka wyrazów i wyrażeń służących do jego werbalizacji, (w:) A. Walulik, J. Mółka (red.), Septuaginta pedagogiczno-katechetyczna, 65-74, Kraków: Wydawnictwo Akademia Ignatianum w Krakowie.

Siuda, P. (2016). (red.). Metody badań online, Gdańsk: Wydawnictwo Naukowe Katedra.

Stoop, D. (2002). Wybaczyć niewoybaczalne, Kraków: WAM.

Szcześniak, M. (2007). Wdzięczność w świetle wybranych koncepcji psychologicznospołecznych, Roczniki Psychologiczne, 1 (10), 94-109.

Szymańska, P. (2019). Uwarunkowania relacji z rodzeństwem we wczesnej dorosłości, Łódź: Wydawnictwo Uniwersytetu Łódzkiego.

Szymańska, P. (2020). The role of siblings in the process of forming life satisfaction among young adults - moderating function of gender, Current Psychology, doi: https://doi.org/10.1007/s12144-020-00776-3.

Szymczak, W. (2010). Podstawy statystyki dla psychologów. Podręcznik akademicki, Warszawa: Wydawnictwo Difin.

Tanner, J.L. (2005). Recentering during emerging adulthood: A critical turning point in life span human development, (in:) J.J. Arnett, J.L. Tanner (eds.), Emerging adulthood in America: Coming of age in the 21 st century, 21-55, Washington, DC: American Psychological Association.

Walęcka-Matyja, K. (2014). Psychometric properties of the polish adaptation of the Adult Sibling Relationship Questionnaire (ASRQ), Archives of Psychiatry and Psychotherapy, 16 (4), 77-88.

Walęcka-Matyja, K. (2018). Relacje interpersonalne dorostych rodzeństw w aspekcie funkcjonowania psychospołecznego $i$ krytycznych wydarzeń życiowych, Łódź: Wydawnictwo Uniwersytetu Łódzkiego.

Woydyłło, E. (1998). Aby wybaczyć, Warszawa: Akuracik.

Zarzycka, B. (2016). Psychologiczne koncepcje przebaczenia w relacjach międzyludzkich, Paedagogia Christiana, 1 (37), 163-181. 